\title{
The Effect of Teacher's Competence to the Lathe Practice Learning Outcome of Vocational High School Students
}

\author{
Sarwi Asri ${ }^{1}$, Muhammad Nurtanto ${ }^{2}$ \\ \{sarwiasri@mail.unnes.ac.id,mnurtanto23@untirta.ac.id\} \\ ${ }^{1}$ Department of Mechanical Engineering Education, Universitas Negeri Semarang, Semarang, \\ Indonesia \\ ${ }^{2}$ Department of Mechanical Engineering Education, Universitas Sultan Ageng Tirtayasa, Banten, \\ Indonesia
}

\begin{abstract}
This study aimed to figure out the impact of the teacher's competence to the lathe practice learning outcome of Vocational High School (VHS) students. This study was an ex-post facto study. The subjects of this study were all VHS students in Kebumen Regency in grade XI with total amount as 1035 students. The data collection used the questionnaire with Likert scale and documentation. The data was analyzed using regression analysis. The result of the study showed that there was a significant impact from the teacher's competence to the lathe practice learning outcome of VHS students in the significance level as $0,000 \leq 0,05$ and the amount of the contribution was $21,43 \%$.
\end{abstract}

Keywords: teachers' competence, learning outcome, lathe practice

\section{Introduction}

The vocational education is closely related to the fulfillment of labor according to the type of mastered skills. [1] The vocational education is secondary education which prepares students primarily to work in certain fields. The statement above explains that the purpose of vocational education is to produce labor force with competence in certain fields.

Vocational High School (VHS) is a form of school that is equipped with workshop and laboratory practices. Therefore, the practical activities in VHS are inseparable from the use of various facilities and infrastructure to support the learning activities. Referring to the aim of VHS to create graduates who are able to meet the needs of the mid-level labor force in accordance with their competencies, then the VHS must be able to provide the practice facilities related to the competencies that will be achieved.

The vocational education will be efficient if the student learning environment is a replica of the actual workplace. The vocational education will be effective if it is provided using the same methods, equipment and machinery that are needed at work. [2] stated that: "Laboratory facilities for vocational-technical courses must provide the best possible match with industrial equipment, materials, work practices, and standards." This statement explains that the used laboratory facilities in VHS such as equipment, materials, work practices, and standards must be matched with the industrial environment. Laboratory facilities that are suitable for the industrial environment have the aim that students are accustomed to work with the actual work situations. 
[2] There are three fundamental areas of facilities planning: physical plant, equipment selection, and equipment organization." [3] the minimum standard of facilities and infrastructure that must be met by every major in VHS. Every Vocational School should meet the minimum standards that have been set so that learning activities can be carried out properly.

[4] that every education unit shall have infrastructure such as land, classroom, education unit head room, educator room, administration room, library, laboratory, workshop, production unit room, canteen, power installation and service, exercise room, prayer room, playground, creative room, and other place/ room required to support the regular and sustainable learning process. From this statement can be concluded that every education unit shall have facilities and infrastructure required to support the regular and sustainable learning process. The study result of [5] Asri stated that there is significant impact from the facilities completeness to the student's practical learning outcome. So that with the fulfillment of facilities and infrastructure completeness will give positive effect for the student's success in obtaining the sufficient information, knowledge and skill.

The facilities completeness in a workshop must be supported by the facilities and infrastructure management itself. The understanding about workshop and leadership management from the teacher and technician is very important as a part of workshop manager. [2] the administration tasks related to the learning and laboratory program implementation. The tasks must be understood well by the vocational teacher. The vocational teacher as the head of workshop and educator must have the knowledge about the learning program and laboratory management so that they will be able to give instruction to the technician and students in teaching and managing the laboratory well. [2] also mentioned that the productive teacher manages the workshop and runs the program in the learning activity. Based on the statement above can be concluded that the productive teacher must master the knowledge to manage the workshop and run the program in the practical learning activity.

Teacher as the educator shall have several requirements. The requirements as [6] the teacher's work achievement standard in performing the professional task, the teacher shall prepare the lesson plan, perform the teaching process which is qualified and assess and evaluate the learning outcome.

The quality of education and graduation is often considered to depend on the role of the teacher in managing the teaching components used in the teaching and learning process. Teacher's competence improvement is expected to have an effect in improving the quality of HR output produced in the education process. The teacher must possess and display maximum competence during the learning activities by adjusting the development of science and technology. [7] stated that the teacher is a professional educator with the main task to educate, teach, guide, lead, train, assess and evaluate the students in the formal education, elementary education and secondary education. The teacher shall possess the ability or competence about the material widely and deeply in this case including the mastery of other academic ability which acts as the professionalism of the teacher.

\section{Methods}

This study was an ex-post facto study because it did not give treatment or manipulation to the study variable. This study exposed the fact based on the indications happened to the previous respondent. The ex-post facto study was included to the correlational study type because aimed to figure out the impact of related variable to a studied object or subject. This study was 
quantitative where the studied indication was measured using the numbers so that the statistics analysis technique for processing the data.

The analysis step used in this study by using the regression analysis started by analysis precondition test and hypothesis test in the regression analysis. The hypothesis test started by determining the line equation:

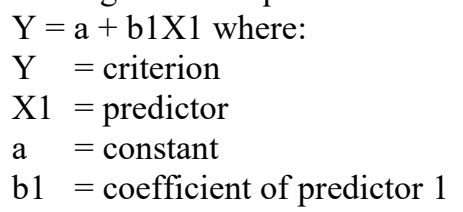

then looked for the correlation of the independent variable to the dependent variable. The correlation coefficient was used to calculate the coefficient of determination so that the magnitude of the influence of the independent variable on the dependent variable was known.

\section{Findings}

The data was collected by closed questionnaire. From the analysis result it was known that the maximum value of the teacher's competence variable was 79 and the minimum value was 44. From the calculation obtained that the average value (Mean) was 64,3719 , mode (M) was 61, Median (Me) was 64, and the Standard Deviation was 6,50151.

The obtained data needed to determine the amount of interval class so that could be easier to be tabulated. The method used to determine the interval class amount was formulation $\mathrm{K}=1$ $+3.3 \log \mathrm{n}$, so that obtained the mathematics equation $\mathrm{K}=1+3.3 \log 285=9.1$ rounded become 9 , while to determine the class length conducted by finding the data range by reducing the maximum score with the minimum score and then added by $1, \mathrm{RD}=($ maximum - minimum $)+$ $1=(79-44)+1=36$. The class length can be found by dividing the data range with total class $=\mathrm{RD}: \mathrm{K}=36: 9=4$.

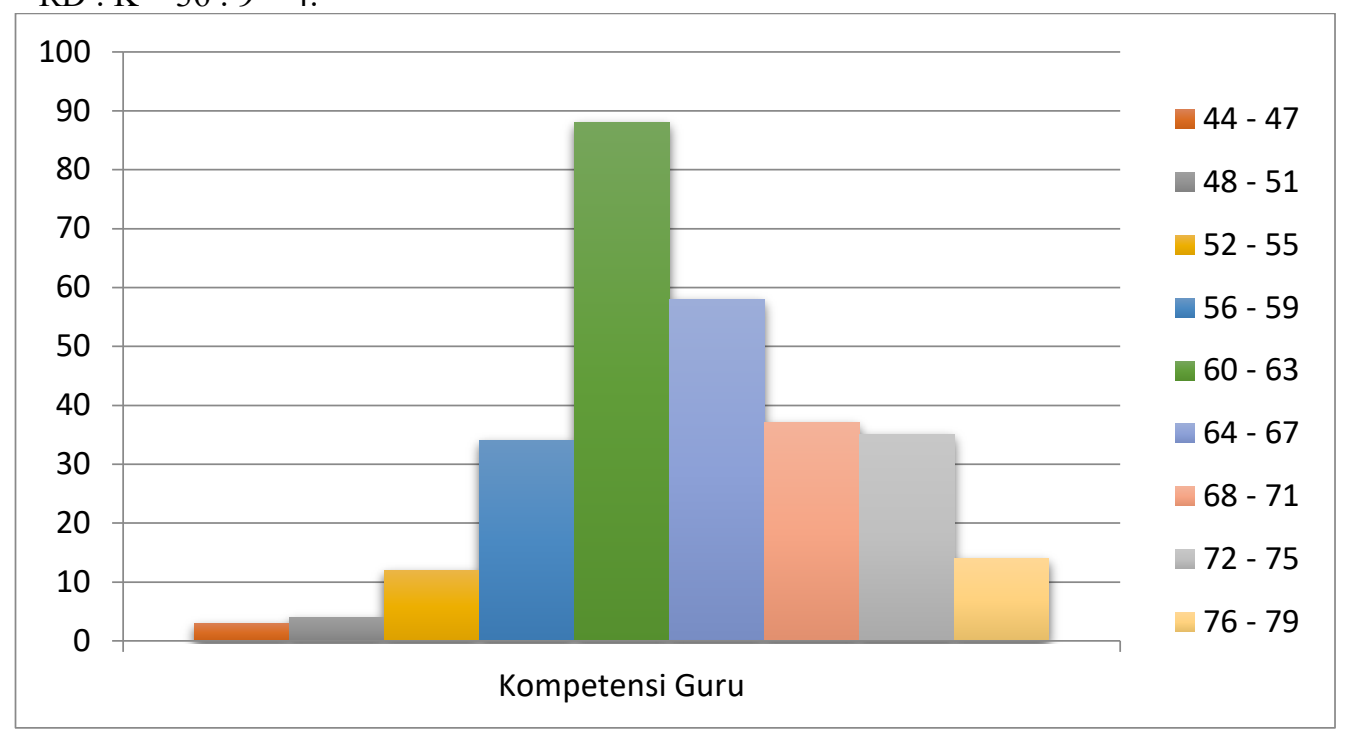

Fig. 1. Histogram of Teacher's Competence

Based on the histogram above about the frequency of teacher's competence of VHS in Kebumen Regency the most frequency was in interval class $60-63$ as 88 persons. 
On the variable of student practical learning outcome obtained the analysis result data in the form of maximum score of the lathe practice learning achievement of the VHS students in Kebumen Regency was 95 and the minimum score was 63. Based on the calculation obtained the average (Mean) score as 81,5, Mode (Mo) as 83, median (Me) as 81.5, and the Standard Deviation was 6,73780.

From the obtained data, it was needed to determine the interval class amount so that it could be easier to be tabulated. Determined the interval class amount by using the formula $\mathrm{K}=1+$ $3.3 \log \mathrm{n}$, so that obtained the mathematical equation $\mathrm{K}=1+3.3 \log 285=9.1$ which was rounded become 9 , while to determine the class length conducted by finding the data range by reducing the maximum score with the minimum score and then added by $1, \mathrm{RD}=$ (maximum minimum $)+1=(95-63)+1=33$. The class length can be found by dividing the data range with total class $=\mathrm{RD}: \mathrm{K}=33: 9=3.67$ which was rounded become 4 .

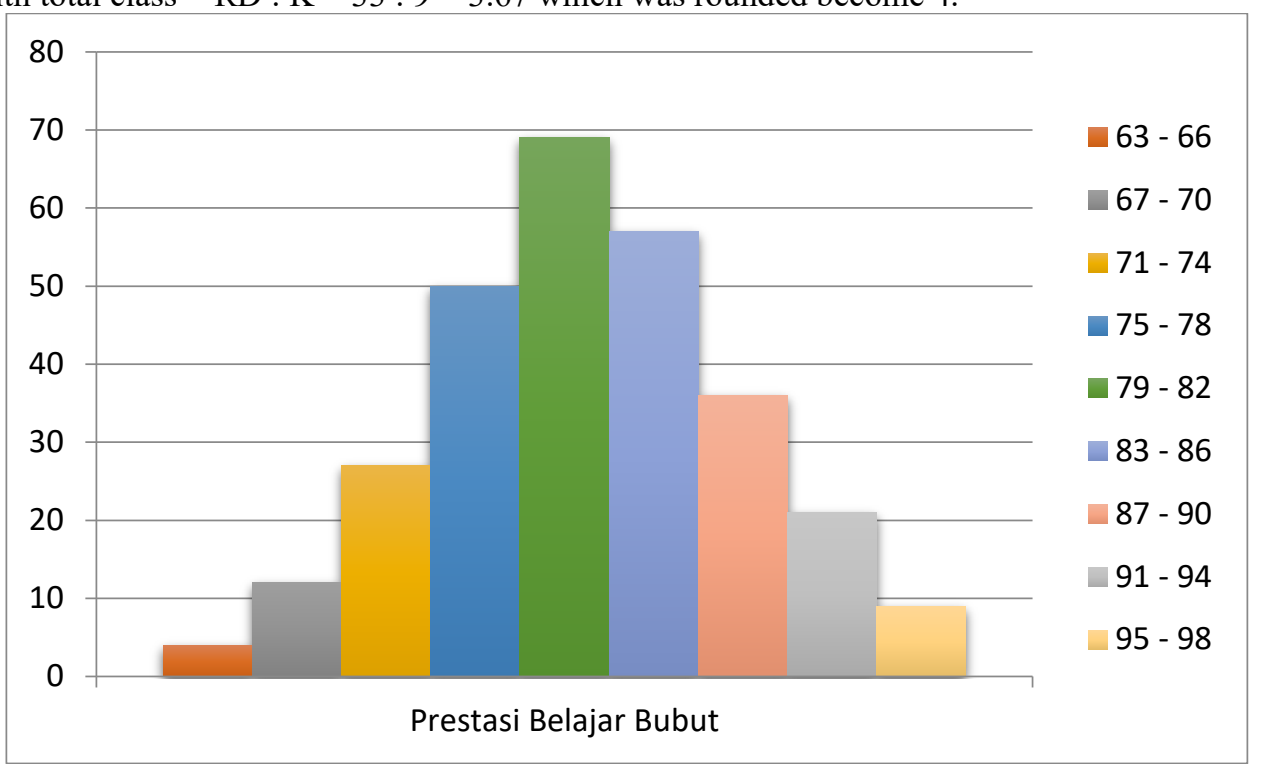

Fig. 2. Histogram of Student's Lathe Practice Learning Outcome

Based on the histogram above about the frequency of teacher's competence of VHS in Kebumen Regency the most frequency was in the interval class $79-82$ as 69 persons. Before the hypothesis test was conducted by the used analysis technique, there were requirements that must be fulfilled, such as the score distribution must be normal and the relation of independent variable and dependent variable was a linear relation.

The calculation result of normality test can be seen on Table 1 .

Table 1. Summary of Normality Test Result

\begin{tabular}{|c|l|c|c|c|}
\hline No & \multicolumn{1}{|c|}{ Variable } & Kolmogorov Smirnov & p & Conclusion \\
\hline 1. & Teacher's Competence (X1) & 1.185 & 0.061 & Normal \\
\hline 2. & $\begin{array}{l}\text { Lathe Practice Learning } \\
\text { Outcome }(Y)\end{array}$ & 1.185 & 0.143 & Normal \\
\hline
\end{tabular}

Based on the normality test result above can be concluded that the variable of facility completeness competence, workshop management, teacher's competence, and lathe practice learning outcome has data distribution with normal distribution. This case was proved by the probability in all variables had $\mathrm{p}$ calculate $>\mathrm{p}$ critical score $(0.05)$. 
Table 2. Summary of Linearity Test Result

\begin{tabular}{|l|l|l|c|c|}
\hline No & Variable & F calculate & Significance & Conclusion \\
\hline 1. & X1 and Y & 0.891 & 0.637 & Linear \\
\hline
\end{tabular}

The decision making for this linearity test was by consulted the probability of $\mathrm{p}$ calculate score with $p$ critical $(0.05)$. If the $p$ calculate score $>p$ critical, then the relation pattern of each variable was linear. Based on the linearity test result on the table above can be concluded that the relation between independent variable and dependent variable has linear relation. It cause by the p calculate score $>$ p critical.

The hypothesis test was conducted by regression analysis. The naught hypothesis (Ho) need to be submitted before the statistics analysis was conducted for the alternative hypothesis verification (Ha). Ho or naught hypothesis of this study was there is not significant impact from the teacher's competence to the lathe practice learning outcome of VHS students. The hypothesis test used regression analysis with the assistance of SPSS software. The decision was taken from the significance score of t-test score. The Ha acceptance guideline that was the t-test significance score $\leq 0.05$. Table 3 below presented the data of hypothesis test result in this study.

Table 3. Summary of Hypothesis Test Result

\begin{tabular}{|c|c|c|c|c|c|c|}
\hline No & Variable & $\mathbf{R}$ & $\mathbf{R 2}$ & t-test & $\begin{array}{c}\text { Significance } \\
\text { of t-test }\end{array}$ & Conclusion \\
\hline 1. & $\mathrm{X} 1$ to Y & 0.487 & 0.237169 & 4.404 & 0.000 & Ha accepted \\
\hline
\end{tabular}

Based on the result above the significance score was under 0.05 in the rejection area of Ho. Therefore it can be concluded that Ho was rejected while Ha was accepted that there was a significant impact on the teacher's competency to the lathe practice learning outcome. This hypothesis conclusion was attested where the significance was $0.000 \leq 0.05$.

\section{Discussion}

The regression line equation from this study was:

$$
\mathrm{Y}=29.861+0.252 \mathrm{X} 1
$$

It implied that if the teacher's competence was increased as 1 point then the lathe practice learning outcome would increase as 0.252 point. The meaning of the regression analysis result above showed that the higher the teacher's competency, the better the lathe practice learning outcome. It signified that there was significant impact on the teacher's competence to the lathe practice learning outcome.

The amount of contribution of workshop management was showed by the result of determination coefficient calculation (R2). From the analysis result it was known that R2 score as 0.237169 . It implied that the variable of teacher's competence gave contribution to the improvement of lathe practice learning outcome of VHS students in Kebumen Regency. It was in line with the statement of [8] (1) teacher's competence as a criteria of teacher recruitment, (2) teacher's competence is important in order to teacher's development, (3) teacher's competence is important in order to curriculum planning, (4) teacher's competence is important in the relation with the student's learning activity and outcome.

The variable of teacher's competence had significant impact to the lathe practice learning outcome. It happened because the teacher as learning activity organizer had important role in delivering the learning materials. The teachers who had special expertise would be able to educate, teach, guide, lead, train, assess and evaluate the students and had authority as well as responsibility to their students. In the fourth point of the above paragraph it was explained that 
the teacher's competence was important in the relation with the students' learning activity and outcome.

The result of the study showed that the variable of teacher's competence had contribution as $23.71 \%$. The contribution number as $23.71 \%$ was considered as small number. It happened because the productive teacher possessed by most of the private school as the subject of the study were not suitable to the qualification of productive teacher of Machinery Engineering.

Considering the importance of teacher's competence in improving the lathe practice learning outcome quality, then the stakeholders of VHS in Kebumen Regency must have high level of awareness to improve the Machinery Engineering teacher's competence. The teacher's competence has been proven to be able to improve the students' learning outcome in lathe practice learning outcome significantly. Therefore the school party need to take the steps which could improve the teacher's competence existed in each school.

The steps that can be taken by schools are by recruiting teachers and technicians according to their qualifications. Moreover, by sending Machinery Engineering teachers to attend the training and education program to improve their competence.

\section{References}

[1] Billett, Stephen. (2011). Vocational Education: Purposes,Traditions and Prospects. New York: Springer.

[2] Brown, R.D. (1979). Industrial education facilities: ahandbook for organization and management. Boston:Allyn and Bacon.

[3] Mendiknas. (2008). Peraturan Menteri PendidikanNasional Republik Indonesia Nomor 40, Tahun 2008,tentangStandar Sarana dan PrasaranaSekolahMenengahKejuruan/Madrasah Aliyah Kejuruan(SMK / MAK).

[4] Presiden. (2005). PeraturanPemerintahNomor 19, Tahun2005, tentangStandar Nasional Pendidikan.

[5] Asri, S., Setiyawan, A., \&Anggoro, A. B. (2019). The Effect of Completeness of Facilities on the Learning Outcome in Lathe Practice of the Students of Vocational High Schools in Kebumen Regency. 379(Veic), 113-118.

[6] Republik Indonesia. (2005). Undang-Undang RI Nomor 14, Tahun 2005, tentang Guru danDosen.

[7] Presiden. (2008). PeraturanPemerintahNomor 74,Tahun 2008,tentang Guru danDosen.

[8] Hamalik, Oemar. (2003). Guru dalamPendekatanKompetensi. Jakarta: BumiAksara. 